\title{
Artikel
}

\section{Kinderrechten als Kompas}

\author{
In vier stappen naar het beste besluit voor het kind
}

Prof. dr. mr. M.E. Kalverboer en mr. L. Van den Heuvel*

\section{Het beste besluit voor het kind?}

De 16-jarige Guus en Abel worden 's nachts angehouden door de politie. Ze worden verdacht van vernieling van een sleutelkastje. De jongens moeten mee in de politieauto, hun mobiel wordt ingenomen en ze worden opgesloten in een cellencomplex.

In de cellen naast hen zitten volwassenen. Sommigen zijn onder invloed of verward. Hun geschreeuw is door de celmuren heen te horen. Guus en Abel zitten de rest van de nacht opgesloten. Ze hebben geen contact met een advocaat en ook niet met hun ouders. Die weten zelfs niet dat hun zoons zijn opgepakt. Zij maken zich grote zorgen als de jongens maar niet thuiskomen. Pas de volgende morgen worden de ouders ingelicht. Guus en Abel worden na een hele nacht in de cel verhoord. Dan horen ze dat ze hun straf af kunnen doen via bureau HALT.

Dat loopt met een sisser af, zou u nu kunnen denken. Maar de gevolgen van de nacht in een cel zijn groot voor de jongens. Ze zijn bang geweest. Ze voelden zich behandeld als zware criminelen. Ze hebben hun vertrouwen in de politie verloren. Elke dag denken de jongens aan de gebeurtenissen van die nacht, ook nog maanden later. Zowel Guus als Abel voelt zich niet goed, ze lopen op school achterstanden op en blijven zitten.

Prof. dr. mr. M.E. is Kinderombudsman. Mr. L. van den Heuvel is beleidsadviseur bij de Kinderombudsman.
Als volwassenen vergeten we soms hoe groot de impact op kinderen is van besluiten die wij nemen. Was het voor Guus en Abel anders gelopen als de politie bij het besluit om hen die nacht op te sluiten had geweten hoe groot de gevolgen voor de jongens zouden zijn? Hadden ze de jongens dan naar huis laten gaan en de volgende dag voor verhoor laten terugkomen?

Politieagenten, maar ook kinderrechters, hulpverleners en anderen die met en voor kinderen werken, nemen vaak moeilijke besluiten. Plaats je een kind uit huis dat thuis mishandeld wordt? Is het voor een kind beter om bij zijn vader of zijn moeder te wonen? Sluit je een kind op in een cel als je de ouders niet kan bereiken? Ingewikkelde besluiten die veel invloed hebben op het leven van een kind. Besluiten waarbij veel verschillende belangen spelen en de advocaat als belangenvertegenwoordiger van deze kinderen soms twijfelt of het besluitvormingsproces en de uitkomst daarvan op een goede manier zijn verlopen. Wat zegt het Kinderrechtenverdrag daarover en waar kan een advocaat zijn wederpartij op aanspreken? En daarnaast, hoe doet een advocaat het zelf: het beste besluit voor een kind nemen. Want ook de advocaat als belangenbehartiger van een kind neemt besluiten die impact hebben op het leven van kinderen.

In dit artikel leest $\mathrm{u}$ hoe het Kinderrechtenverdrag kan helpen bij het beantwoorden van de vaak lastige vraag welke vereisten gesteld worden aan het onderzoeken en vaststellen van het belang van het kind en hoe in een besluitvormingsprocedure in vier praktische stappen tot het beste besluit voor het kind kan worden gekomen. 


\section{Sleutelartikelen Kinderrechten-}

\section{verdrag in relatie tot General \\ comment 14: het belang van het kind}

Kinderen hebben recht op besluiten waarin hun belang vooropstaat, zo bepaalt artikel 3 van het Kinderrechtenverdrag (IVRK). Dit artikel is een van de vier sleutelartikelen uit het IVRK. De andere drie sleutelartikelen zijn artikel 2 waarin het non discriminatiebeginsel is opgenomen, artikel 6 over het recht op leven en ontwikkeling en artikel 12 betreffende het recht om gehoord te worden. Artikel 3 moet in bijzondere samenhang met deze drie andere sleutelartikelen gezien worden. Het in samenhang tot elkaar zien van kinderrechten wordt ook wel de holistische benadering van het IVRK genoemd.

Wat betekent deze samenhang nu precies met betrekking tot 'het belang van het kind' en hoe stel je dat belang vast? In de praktijk blijkt dat vaak lastig. Daarom heeft het VN-Kinderrechtencomité in 2013 een General Comment ${ }^{1}$ uitgebracht met een nadere uitleg van artikel 3. General Comment 14 gaat in op hoe het belang van het kind onderzocht en vastgesteld dient te worden.

In de richtlijn benadrukt het Kinderrechtencomité dat een belangenafweging moet worden gemaakt bij elke beslissing die gevolgen heeft voor een kind of groep kinderen. Over de manier hoe je dat doet worden expliciet aspecten van de andere sleutelartikelen meegenomen. Zo is het belang van het kind te beschouwen als diens ontwikkelingsbelang. Dit kun je alleen maar onderzoeken als je het kind hierover gehoord hebt en je het kind gelijk hebt behandeld als andere kinderen in een vergelijkbare situatie.

Een goed onderbouwd besluit vraagt volgens het Kinderrechtencomité verder om een kindvriendelijk, volledig onderzoek, bij voorkeur uitgevoerd door een multidisciplinair team. Het onderzoeken van de belangen van het kind, de 'best interests of the child assessment' (afgekort tot: BIC-assessment), gaat vooraf aan het nemen van het werkelijke besluit - bijvoorbeeld door een rechter - de 'best interest of the child determination'. Zo kan een advocaat het belang van het kind (laten) onderzoeken en ter zitting inbrengen, vervolgens stelt de rechter het belang van het kind vast in zijn of haar vonnis.

Het Kinderrechtencomité heeft alle bij het verdrag aangesloten landen opgeroepen om General Comment 14 breed te verspreiden onder parlementen, regeringen en de rechterlijke macht, zowel op nationaal als lokaal niveau. De richtlijn moet ook bekendgemaakt worden aan alle kinderen en aan alle professionals die voor en met kinderen werken, waaronder rechters, advocaten,

1. General Comment no. 14 (2013) on the right of the child to have his or her best interests taken as a primary consideration, CRC/C/GC/14, 29 mei 2013 voogden, maatschappelijk werkers, zorgpersoneel en het maatschappelijk middenveld in het algemeen. Daarnaast moet de richtlijn een plek krijgen in de opleidingen van professionals. Het comité zegt ook dat de richtlijn uitgewerkt moet worden voor alle verschillende besluitvormingsprocedures waarmee kinderen te maken kunnen krijgen.

\section{Van richtlijn naar praktisch stappenplan}

General Comment 14 geeft dus inzicht in hoe het belang van het kind onderzocht en vastgesteld moet worden om zo een goed besluit te nemen waarbij het belang van het kind een eerste overweging vormt. Het geeft daarmee vorm aan de holistische benadering van kinderrechten. Het General Comment is een weinig toegankelijke tekst. Daarom heeft de Kinderombudsman de richtlijn van het Kinderrechtencomité bewerkt tot een basishandreiking: een praktisch stappenplan, 'Het beste besluit voor het kind', ${ }^{2}$ dat toepasbaar en uit te werken is voor ieder rechtsgebied en ieder type besluit dat de belangen van een kind kan raken.

Iedereen die met of voor kinderen werkt, kan in vier stappen het belang van het kind onderzoeken en vast (laten) stellen door: 1) te onderzoeken wat het beste is voor de ontwikkeling, het ontwikkelingsbelang, van het kind, 2) de andere belangen in kaart te brengen, 3) een afweging te maken tussen wat het beste is voor de ontwikkeling van het kind en alle andere belangen die een rol spelen en 4) door de beslissing uit te leggen aan het kind.

\section{Stap 1: Onderzoek het belang van het kind}

Het Kinderrechtencomité wil dat alle professionals en instanties, en dus ook de instanties tegen wie bijvoorbeeld een advocaat in het geweer komt, volgens eenzelfde methodiek onderzoeken wat het beste is voor het kind. Om tot een goed onderzoek naar het belang van het kind te komen, moet allereerst worden bepaald welke elementen relevant zijn voor het onderzoek naar het ontwikkelingsbelang van het kind. Op basis van artikelen uit het Kinderrechtenverdrag moeten volgens het comité de volgende elementen in het onderzoek in ieder geval worden meegenomen:

\section{Identiteit van het kind}

Over wie gaat de beslissing eigenlijk? Wat maakt dit kind speciaal? Hou rekening met het kind, denk hierbij onder andere aan geloof, cultuur, geslacht en leeftijd.

2. Het beste besluit voor het kind: www.dekinderombudsman.nl/toolkitbeste-besluit. 
BESLISSING IN 4 STAPPEN:

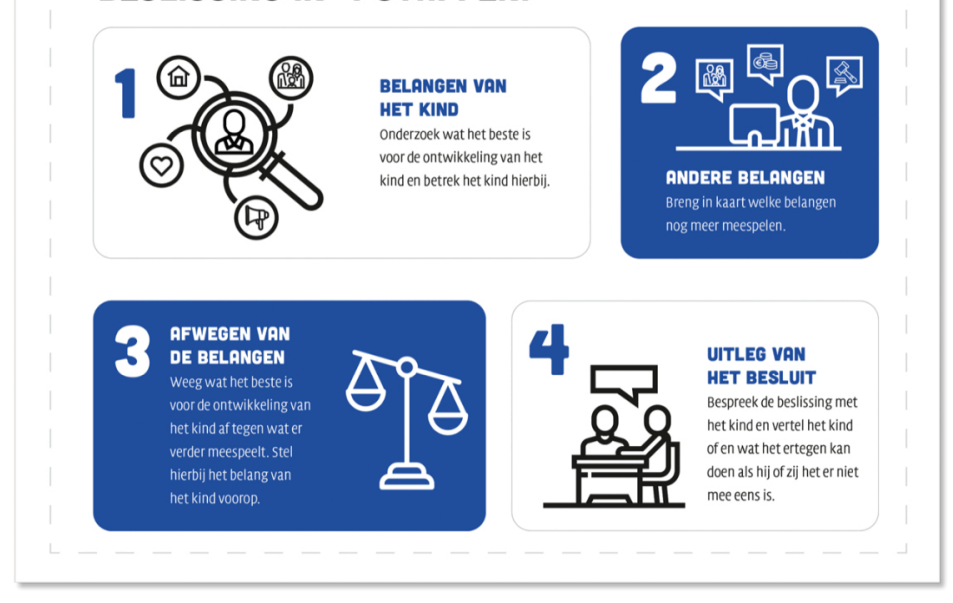

2. Mening van het kind over de situatie en de te nemen beslissing

Wat wil het kind zelf, wat vindt het kind het meest ideale besluit en waarom?

3. Behoud van de gezinsomgeving en belangrijke contacten

Wat betekent het te nemen besluit voor bij wie het kind woont en voor het contact met belangrijke personen in het leven van het kind?

4. Zorg, bescherming en veiligheid

Wat voor invloed heeft het te nemen besluit op de bescherming, verzorging en veiligheid van het kind?

5. Kwetsbare kinderen of bijzondere situaties

Hoe moet rekening worden gehouden met extra bijzonderheden van het kind, zoals een beperking, trauma, sociale status of een laag of hoog IQ?

6. Recht van het kind op gezondheid

Wat betekent het te nemen besluit voor de gezondheid van het kind?

7. Recht van het kind op onderwijs

Wat voor invloed heeft het te nemen besluit op het volgen van (passend) onderwijs?

Daarnaast zijn er elementen - die eveneens terug te voeren zijn op de rechten uit het kinderrechtenverdrag die specifiek gerelateerd zijn aan de situatie waarin een kind verkeert. Ook aan deze elementen moet gewicht worden gegeven bij de vaststelling van het ontwikkelingsbelang van het kind.

Aan de hand van het onderzoek in deze eerste stap krijgt $\mathrm{u}$ een beeld welk besluit het beste is voor de ontwikkeling van het kind, los van alles wat verder speelt. Dat is het ideale besluit voor het kind wanneer $\mathrm{u}$ werkelijk alleen dat zou laten tellen. Daarbij maakt $u$ een inschatting van de gevolgen van het besluit voor zijn toekomst, zowel op korte als lange termijn.

\section{Stap 2: Breng de overige belangen in kaart}

Naast de belangen van het kind spelen ook andere belangen, bijvoorbeeld rond openbare orde, normstelling, vergelding, wat de wensen van de ouders zijn, wat betrokken organisaties willen en kunnen en of er voldoende geld is voor de gewenste oplossing. Ook kunnen er wetten en regels zijn die een obstakel vormen voor de beste oplossing voor het kind. In stap 2 maakt u een overzicht van alle 'niet-kindbelangen' waarmee rekening gehouden moet worden bij het te nemen besluit. Deze kunnen tegen het belang van het kind ingaan.

\section{Stap 3: Weeg de verschillende belangen af en neem een beslissing}

Is het duidelijk wat het beste is voor (de ontwikkeling van) het kind en welke andere belangen meespelen? Dan kunt $u$ op basis van deze informatie een aantal mogelijke besluiten uitwerken. Vervolgens wordt het besluit genomen. Misschien door u zelf, maar mogelijk door een rechter of een zorgaanbieder. Dit besluit wordt goed gemotiveerd, waarbij degene die het besluit neemt alle factoren noemt waarmee rekening is gehouden en weergeeft hoe diegene deze tegen elkaar heeft afgewogen. Ook brengt degene die het besluit neemt, in kaart hoe het belang van het kind terugkomt in de beslissing. Wanneer degene die het besluit neemt, niet kiest voor wat het beste is voor het ontwikkelingsbelang van het kind, motiveert diegene zijn of haar keuzes extra. 


\section{Stap 4: Bespreek de keuze met het kind}

Het besluit wordt altijd in begrijpelijke taal aan het kind uitgelegd. Hierbij vertelt degene die het besluit neemt niet alleen welke beslissing is genomen, maar ook hoe het besluit is genomen en op welke manier rekening is gehouden met het kind. Ook vertelt de besluitnemer of er iets tegen het besluit gedaan kan worden als een kind het er niet mee eens is en, zo ja, wat het kind of zijn ouders hiertegen kunnen doen.

\section{Het beste besluit voor het kind}

Waren Guus en Abel die nacht opgesloten geweest als de politie bij het nemen van het besluit de vier stappen had gevolgd? Mogelijk was hetzelfde besluit genomen, mogelijk ook niet. In het laatste geval had de politie de jongens inzichtelijk kunnen maken hoe tot het besluit was gekomen. Waarom hun belang in dezen niet geprevaleerd had en gekozen was voor andere belangen. Men was zich meer dan nu bewust geweest van de eigen afweging. Er was bij eenzelfde besluit wellicht beter over het besluit gecommuniceerd. En mogelijk waren er andere keuzes gemaakt en bij het ontwikkelingsbelang van de jongens aansluitende oplossingen gevonden.

Tot slot: het stappenplan is uitdrukkelijk geen exercitie die ertoe leidt dat dé goede beslissing eruit komt. Het kan zelfs zo zijn dat het uiteindelijke besluit na het doorlopen van de vier stappen niet het beste besluit voor het kind is dat uit stap 1 is gekomen. Dit omdat daarvoor allerlei praktische belemmeringen zijn dan wel omdat bijvoorbeeld maatschappelijke belangen zwaarder dienen te wegen.

Waar het om gaat, is dat we ons bewust zijn van wat het belang van het kind is, dat we een goede afweging maken en we ons uiterste best doen om een besluit te nemen dat hieraan rechtdoet. Dat vraagt om een andere manier van denken. De vraag die centraal moet staan bij alle besluiten die invloed hebben op kinderen is: wat heeft dit kind nodig om zich nu en in de toekomst zo goed mogelijk te ontwikkelen en hoe gaan wij dit zo goed mogelijk realiseren?

En dat is nodig. Want in de praktijk komt de vraag wat het kind precies nodig heeft vaak pas laat aan bod, of wordt die vraag zelfs helemaal overgeslagen. Want we denken als volwassenen te weten wat het beste is voor het kind, zonder het kind hier zelf naar te vragen, omdat we door urgentie dan wel financiële aspecten meteen in pragmatische oplossingen denken. Belangen van organisaties staan immers voorop: wie is verantwoordelijk, welke hulp is ingekocht, wie gaat het betalen? Door te beginnen bij stap 1, het zuiver onderzoeken van het belang en ontwikkelingsperspectief van het kind, zetten we het kind weer centraal.
Het stappenplan zoals dat nu voorligt, is samen met jeugdprofessionals en jongeren ontwikkeld. De komende jaren zal de Kinderombudsman ook andere hulpmiddelen maken voor het nemen van besluiten voor en met kinderen waarbij het Kinderrechtenverdrag als kompas dient. Deze hulpmiddelen zijn zowel bestemd voor professionals als voor kinderen en worden stap voor stap afgestemd op de verschillende sectoren, van onderwijs tot politie. De eerste pilot wordt op dit moment gedraaid met organisaties uit de jeugdzorgsector.

Wat heeft dit kind nodig om goed op te groeien en hoe gaan wij dit realiseren? Oftewel: welk besluit is in het (ontwikkelings)belang van een kind en is dit, afgewogen tegen alle andere belangen, mogelijk? Door het volgen van de vier stappen ontstaat inzicht in wat het beste is voor het kind en wat er verder meespeelt en hier mogelijk aan in de weg staat. Met het Kinderrechtenverdrag als kompas bereiken we dat professionals - of het nu rechters zijn of hulpverleners - op overzichtelijke, navolgbare wijze besluiten nemen, waarbij ze op inzichtelijke wijze rekening houden met het ontwikkelingsbelang van het kind en zich ervan bewust zijn dat in de praktijk dit ontwikkelingsbelang niet vanzelfsprekend een eerste overweging is.

Meer informatie over 'Het beste besluit voor het kind': www.dekinderombudsman.nl/toolkit-beste-besluit. 